\title{
Literary Analysis of Covenant Themes in the Book of Malachi*
}

\author{
BLESSING ONORIODE BOLOJE ${ }^{1}$ AND ALPHONSO GROENEWALD (UP)
}

\begin{abstract}
The category of covenant is considered to be the dominant and cohesive idea in the theology of the OT. It is the means through which Israel conceptualise its relation with Yahweh. Although the term "covenant" is variously and even contradictorily defined, its applicability to Israel's conceptualisation of its relationship with Yahweh is pervasive and well-known. The covenant relationship between Israel and Yahweh is considered to be its constitution, its vocation, and its salvation. From a theological view point, the essential components of Malachi's oracles are the personhood of Yahweh - the God of Israel, Yahweh's covenant relationship with Israel, and the all-pervasive message of unreserved and enthusiastic personal response of Israel to the truth assertions of the prophetic voice. This article thus demonstrates the significance of covenant as the central and cohesive theological motif connecting and coordinating several themes present in the book of Malachi as well as illuminating its message. In Malachi, one observes that certain religious fundamentals were compromised. In order to deal with the indifference and its adverse consequences in the gradual decline towards an unstructured existence and to hold together a society that upholds values and maintains an ancient faith, Malachi was skilful and creative in his employment of the covenant theme to the advantage of his ministerial context. The article presents precise background and historical information about the book of Malachi that are crucial to an understanding of its theme and message, the book's literary style, theme and structure, examines the various covenant themes and then concludes by synthesising these themes with the overall message of the book's context.
\end{abstract}

Keywords: Covenant, book of Malachi, Yahweh's covenant relationship, election, OT theology, Israel

* To cite: Blessing Onoriode Boloje and Alphonso Groenewald, "Literary Analysis of Covenant Themes in the Book of Malachi," OTE 28, no. 2 (2015: 257-282. DOI: http://dx.doi.org/10.17159/2312-3621/2015/v28n2a4

1 Lecturer at the Baptist Theological Seminary, Eku, Nigeria and Postdoctoral Fellow, Department of Old Testament Studies, Faculty of Theology, University of Pretoria with Prof. Dr. A. Groenewald as research leader. His current research project at the University of Pretoria is an extension of the primary aims and objectives of his doctoral thesis ("Malachi's view on temple rituals and its ethical implications"). 


\section{A INTRODUCTION}

The concept of covenant is considered to be the dominant and cohesive theme in the theology of the OT. ${ }^{2}$ It is of fundamental significance in OT religion ${ }^{3}$ and thus fits best in the theology of God's dealing with humanity. ${ }^{4}$ Although the term "covenant" is variously and even contradictorily defined, ${ }^{5}$ its applicability to Israel's conceptualisation of its relationship with Yahweh is pervasive and well-known. ${ }^{6}$ George E. Mendenhall holds that, "the relationship between God and man is established by a covenant."7 Covenant is a word that is used quite frequently in both the OT and the NT with numerous biblical theologians arguing that all of the OT can be understood in terms of covenant. ${ }^{8}$ Walther Eichrodt underscores the theme of covenant to be the core of biblical studies. ${ }^{9}$ The significance of the concept of covenant for the understanding of the OT took on a fresh and far reaching importance from about the middle of the last century

2 Gerhard Hasel, Old Testament Theology (Grand Rapids: Eerdmans, 1972), 20.

3 George W. Anderson, The History and Religion of Israel (Oxford: University Press, 1989), 35.

4 Gary D. Badcock, "God of the Covenant," in Covenant Theology (ed. Mark J. Cartledge and David Mills; Waynesboro, Ga.: Paternoster Press, 2001), 67-84 (69).

5 Covenant describes Israelite conceptions of their relationship with Yahweh. It belongs to the category of something which is spoken about Yahweh's relationship to particular persons, to his people, or to the whole of human race. See Norbert Lohfink, Covenant Never Revoked (New York: Paulist, 1991), 21. Further definitions of the word are presented in the fourth section of this article: analysis of covenant themes in the book of Malachi.

6 Robert D. Miller, Covenant and Grace in the Old Testament: Assyrian Propaganda and Israelite Faith (PHSC 16; Piscataway, N.J.: Gorgias Press LLC, 2012), 1.

7 George E. Mendenhall, "Covenant Forms in Israelite Tradition," BA 17 (1954): $50-76(50)$.

8 Biblical theologians have examined covenant along various assumed dimensions such as between unqualified Abrahamic covenant and Israel's conditional covenant, between a God who shows mercy and the One that requires submission. See Walter Bruggemann, Theology of the Old Testament: Testimony, Dispute, Advocacy (Minneapolis: Fortress Press, 1997), 199, 419-21; Gary Knoppers, "Ancient Near Eastern Royal Grants and Davidic Covenant," JAOS 116 (1996): 670-697 (696, 695-696); Bruce K. Waltke, "The Phenomenon of Conditionality within Unconditional Covenants," in Israel's Apostasy and Restoration: Essays in Honor of Roland K. Harrison (ed. Avraham Gileadi; Grand Rapids: Baker, 1988), 123-139; William J. Dumbrell, "The Prospect of Unconditionality in the Sinaitic Covenant," in Israel's Apostasy and Restoration: Essays in Honor of Roland K. Harrison (ed. Avraham Gileadi; Grand Rapids: Baker, 1988), 141-155; to mention a few.

9 Walther Eichrodt, Theology of the Old Testament (vol. 1; Philadelphia: Westminster, 1961), 13-14. 
when a large number of ANE political treaties (covenants) dating from the first millennia B.C.E. were uncovered. ${ }^{10}$

Within the ANE context, Kessler identifies and describes four important types of covenant as well as provides biblical illustrations of these covenant patterns: first, covenants that were made between two individuals or groups of relatively equal status or power, sometimes called "bilateral parity covenants." Second, covenants made between a greater power and a lesser one, often referred to as "bilateral suzerainty (vassal) treaties." A third type of covenant was that which was imposed by a powerful king or nation upon a less powerful one. These are usually called "loyalty oaths." The fourth type of covenant involved a solemn promise by one party to another to grant a certain benefit or good. These are usually called "promissory covenants, or covenants of grants." Israel's covenant relationship with Yahweh is considered to be its constitution, its vocation, and its salvation. While the idea is a multifaceted one, it includes descriptive norms (though it is more a motive for justice than a source of law) and shared experience of Yahweh's saving acts. It serves as the hermeneutic for interpreting history as continuance of those acts. It adopts a formal structure and involves ritual acts. ${ }^{12}$ This is why Walter Brueggemann has rightly said, "Israel's worship is to be understood as a practice of covenant whereby Israel variously receives and affirms the covenant, maintains and sustains the covenant, and takes steps to renew and revivify the covenant."13

This article intends to demonstrate the significance of covenant as the central and cohesive theological motif connecting and coordinating several themes present in the book of Malachi as well as illuminating its message. In Malachi, the word $b^{e}$ rîth ("covenant") occurs about six times $(2: 4 ; 2: 5 ; 2: 8$; $2: 10 ; 2: 14 ; 3: 1)$, along with several other associated terminologies and with such thought-provoking potential of interpreting the entire book all around this notion. ${ }^{14}$ However, numerous infringements of covenantal relationship are spelt out. The prophet's message with particular reference to certain kinds of unacceptable behaviour: ritual malpractices, inappropriate marriages and associated

10 John Kessler, Old Testament Theology: Divine Call and Human Response (Waco, Tex.: Baylor University Press, 2013), 177-78, 178-179, 181). See also Mendenhall, "Covenant Forms," 50-76, whose studies made some clear convergence of traditions that indicates that covenant in Israel is a characteristic expression that stands as a union of law and treaty. Cf. also Gerhard von Rad, Old Testament Theology (vol. 1; New York: Harper \& Row, 1962), 132, who positively acknowledges connection between biblical covenant traditions and ANE treaties.

11 Kessler, Old Testament Theology, 178-179, 181.

12 Miller, Covenant and Grace, 27.

13 Walter Brueggemann, Worship in Ancient Israel: An Essential Guide (Nashville: Abingdon Press, 2005), 8.

14 Howard N. Wallace and Steven L. Mackenzie, "Covenant Themes in Malachi," $C B Q$ 45/4 (1983): 549-563 (549). 
divorce, failure to tithe and social inequalities are all violations of the responsibility of Yahweh's covenant with Israel. Written at a time following the return from the Babylonian captivity, the book of Malachi illustrates the steady and ongoing infidelity of Yahweh's people in the Second Temple period. The book reflects in many ways prophetic notion at the close of an era and then looks forward to a different kind of future, yet to come. ${ }^{15}$ The book brings its prophetic narrative to an end with a caution concerning an approaching moment of Yahweh's justice and the declaration of the arrival of Elijah the prophet. ${ }^{16}$ In its canonical context, Malachi serves a dual function as both a self contained prophecy and a unified conclusion to the book of the Twelve, ${ }^{17}$ and thus provides an overall framework and clues to the application of the Twelve. ${ }^{18}$ Seen in this context, the remarks of Marvin A. Sweeney become very fascinating:

Finally, Malachi, in its call for renewed observance of the covenant, rehearses various themes from the Twelve, such as the destruction of Edom/Esau, the disrupted covenant between YHWH and Israel, the polluted state of the temple and the priesthood, and the Day of YHWH. In projecting YHWH's appearance, Malachi calls for observance of Mosaic Torah, and thereby recalls the instruction in YHWH's Torah that will be given in Zion (Mic 4); it looks forward to the appearance of Elijah, who is perhaps associated with the allusions to Jehoshaphat in Joel and Obadiah, when Israel turns its heart back to YHWH. Insofar as Malachi expresses YHWH's distaste for divorce and calls for return of Israel to YHWH, it rounds out the themes introduced in the book of Hosea. ${ }^{19}$

In Malachi, one observes that certain religious fundamentals were compromised: did Yahweh actually love Israel and what evidence of Yahweh's justice does one find in his world? These fundamental misgivings affected several other areas of Israel's life. While the priesthood and religious worship lost

15 Peter C. Craigie, The Twelve Prophets (vol. 2; DSB; Philadelphia: The Westminster Press, 1985), 222.

16 John R. Jackson, "Abigail or Asherah: Competing Canonical Readings of Malachi 2.12-16," Leaven 12/1 (2004); Art. \#8, pp. 40-48 (41). Cited 12 February 2012. Online: http://digitalcommons.pepperdine.edu/leaven/vol12/iss1/8.

17 Jason T. LeCureux, The Thematic Unity of the Book of the Twelve (HBM 41; Sheffield: Sheffield Phoenix Press, 2012), 207. See also, Blessing O. Boloje and Alphonso Groenewald, "Malachi's Eschatological Day of Yahweh: Its Dual Roles of Cultic Restoration and Enactment of Social Justice (Mal 3:1-5; 3:16-4:6)," OTE 27/1 (2014): 53-81 (75).

18 John D. W. Watts, "A Frame for the Book of the Twelve: Hosea 1-3 and Malachi," in Reading and Hearing the Book of the Twelve (ed. James D. Nogalski and Marvin A. Sweeney, SBLSymS 15; Atlanta: SBL, 2000), 209-218.

19 Marvin A. Sweeney, "Sequence and Interpretation in the Book of the Twelve," in Reading and Hearing the Book of the Twelve (ed. James D. Nogalski and Marvin A. Sweeney, SBLSymS 15; Atlanta: SBL, 2000), 49-64 (61-62). 
all sense of integrity, intermarriage became widespread and social vices rampant. In order to deal with the indifference and its adverse consequences in the gradual decline towards an unstructured existence and to hold together a society that upholds values and maintains an ancient faith, Malachi was skilful and creative in his employment of the various covenant ideas to the advantage of his ministerial context. As a literary endeavour, the article presents precise background and historical information about the book of Malachi that are crucial to an understanding of its theme and message, the book's literary style, theme and structure, examines the various covenant themes and then concludes by synthesising these themes within the overall context of the book's message.

\section{B BACKGROUND AND HISTORICAL INFORMATION}

Establishing background and historical information about the book of Malachi is crucial to an understanding of its theme and message. Very little is known about Malachi and his time. ${ }^{20}$ While the name Malachi (mal'a $\left.k h \hat{l}\right)$ could have been the actual name of the prophet, or simply "my messenger," that is Yahweh's messenger, as the one who is responsible for the oracles of the book, it is alternatively regarded as a designation for the nameless individual accountable for the compilation of the book. ${ }^{21}$ Although no specific information is presented with regard to the individual life of the writer, ${ }^{22}$ and namelessness or pseudo-anonymity is considered to be a characteristic element of late prophecy, ${ }^{23}$ the book is intrinsically related to the viewpoint that Zech $9-11,12-14$, and Malachi were initially three autonomous and nameless compositions. ${ }^{24}$

20 Elie Assis, "Structure and Meaning in the Book of Malachi," in Prophecy and the Prophets in Ancient Israel: Proceedings of the Oxford Old Testament Seminar (ed. John Day; LHBOTS 531; New York: T \&T Clark, 2010), 354-369 (354).

21 Andrew E. Hill, Malachi: A New Translation with Introduction and Commentary (AB; New York: Doubleday, 1998), 15.

22 Wilhelm Rudolph, Haggai-Sacharija-Maleachi (KAT 13/4; Gutersloh: Mohn, 1976), 247-248.

23 Eric M. Meyers, "Priestly Language in the Book of Malachi," HAR 10 (1986): 225-237 (226); Karel van der Toorn, Scribal Culture and the Making of the Hebrew Bible (London: Harvard University Press, 2007), 31. Although Eileen M. Schuller employed Malachi as a name in her work and followed recognised convention, declared that the oracles in the book of Malachi are basically nameless and operate autonomously of the prophetic personnel. See Eileen M. Schuller, "The Book of Malachi," NIB 6: 843-877 (847).

24 Otto Eissfeldt, The Old Testament: An Introduction (New York: Harper \& Row, 1965), 441; Robert C. Dentan, “The Book of Malachi," IB 6 (1956): 1117-1144 (1137). Beth Glazier-McDonald holds that the three-times recurrent expression $m \bar{a} s^{s} \bar{a}^{\bar{a}}$ ' $d h^{e}$ bhar-yhwh ("The burden of the word of Yahweh"), which appears in Zech 9:1; 12:1 and Mal 1:1, had a history independent of one another and noted that the three oracles (Mal 1:1; Zech 9:1 and 12:1) were nameless. See Beth Glazier-McDonald, Malachi: The Divine Messenger (SBLDS 98; Atlanta: Scholars Press, 1987), 26- 
The various scholarly opinions that consider the author of the book of Malachi as someone who is acquainted with scribal pursuit, ${ }^{25}$ has given rise to the deduction that the author was not a Levite. ${ }^{26}$ His official position provided him a nonprofessional's perception of the priesthood nevertheless, with adequate understanding of its disposition and its structural compositions. ${ }^{27}$ As it is, the book of Malachi breathes the temper and outlook of an innovative, true personality of a prophetic figure. While his date is masked in uncertainty, ${ }^{28}$ evidences within the inner surface structure of the book reveal that the prophecy took place at a time following the return from exile and after the rebuilding of the temple in the Persian era, most likely in the fifth century B.C.E.. ${ }^{29}$ While

27. These three distinct units of prophetic oracles were at a time included in the same prophetic compendium which was later inserted in their current position in the canon randomly. See Louis Stulman and Hyun C. P. Kim, You are My People: An Introduction to the Prophetic Literature (Nashville: Abingdon Press, 2010), 240. See also, David L. Peterson who has observed that these three distinct units of prophetic oracles set up an epilogue both to the three mas' ôth and to the Minor Prophets in its entirety. See David L. Peterson, Zechariah 9-14 and Malachi (OTL; Louisville, Ky.: Westminster/John Knox Press, 1995), 2.

${ }^{25}$ Karl W. Weyde considerers the writer of the book of Malachi as a scribe, one who simply explained ancient traditions that were available to him. See Karl W. Weyde, Prophecy and Teaching: Prophetic Authority, Form Problems, and the Use of Traditions in the Book of Malachi (BZAW 288; Berlin: Walter de Gruyder, 2000), 4-5. Konrad Schmid, holds that the books of Malachi, Joel and Habakkuk should be viewed as being completely the prophecy of scribal tradents. See Konrad Schmid, The Old Testament: A Literary History (Minneapolis: Fortress Press, 2012), 164. See also, Paul L. Redditt, Haggai, Zechariah and Malachi (NCBC; Grand Rapids: Eerdmans, 1995), 153; Jan Christian Gertz, et al., T\&T Clark Handbook on the Old Testament: An Introduction to the Literature, Religion and History of the Old Testament (New York: T\&T Clark International, 2012), 521.

26 Joseph Blenkinsopp notes that Malachi's intense concern for the cult, along with his ferocious attack on the priesthood in addition to its carelessness in ritual ethics, divorce and above all its blasé skepticism in religious matters, suggests that he may have been either a dissident priest turned prophet or a Levite. See Joseph Blenkinsopp, A History of Prophecy in Israel (rev. ed.; Louisville: WJKP, 1996), 209. Malachi, as speculated by Paul L. Redditt was a Levite or represents a Levitical viewpoint. See Paul L. Redditt, "The Book of Malachi in Its Social Setting," CBQ 56/2 (1994): 240-255 (252). See also Rex A. Mason, The Books of Haggai, Zechariah and Malachi (CBC; London: Cambridge University, 1977), 148.

27 Hill, Malachi, 18

28 For majority of scholars, no precise date can be given. However, the range of possibilities is still vast. Assis, "Structure and Meaning," 354; Hill, Malachi, 78-84.

29 Lester L. Grabbe, A History of the Jews and Judaism in the Second Temple Period (vol. 1; ed. Lester L. Grabbe and James H. Charlesworth; LSTS 47; New York: T \& T Clark International, 2004), 87; Robert B. Chisholm, "A Theology of the Minor Prophets," in Biblical Theology of the Old Testament (ed. Roy B. Zuck; Chicago: Moody Press, 2002), 449. 
Boloje and Groenewald, "Literary Analysis," OTE 28/2 (2015): 257-282 263

Malachi is thought to be a ministry colleague of Ezra and Nehemiah, ${ }^{30}$ at the same time the dating of these books has also generated a fair amount of disputation, ${ }^{31}$ it seems likely that the final stage of the book of Malachi can be dated sometime between $475-450$ B.C.E. ${ }^{32}$ From his writing, it is noticeable that Malachi did not live during a period of major political developments or violent situation. The oracles in the book of Malachi reflect everyday life in a context that has been known to be a small province of a great Persian Empire. ${ }^{33}$ Considered to be those who ushered in an era of relative peace that was condu-

30 On the basis of similarities and differences between what Malachi and Ezra/Nehemiah tried to correct see, Sean P. Kealy, An Interpretation of the Twelve Minor Prophets of the Hebrew Bible: The Emergence of Eschatology as a Theological Theme (Lewiston, N.Y.: The Edwin Mellen Press, 2009), 229; Walter C. Kaiser Jr., Malachi: God's Unchanging Love (Grand Rapids: Baker Book House, 1984), 16; Erhard S. Gerstenberger, Israel in the Persian Period: The Fifth and Fourth Centuries B.C.E. (trans., S. S. Schatzmann; Atlanta: Society of Biblical Literature, 2011), 22; Grabbe, History of the Jews, 89-90.

31 Schuller holds that these oracles are fixed more specifically in the decades preceding Ezra and Nehemiah, about 480-450 B.C.E.. See Schuller, "Malachi," 849; Sweeney believes that Ezra's reforms address the issues raised in Malachi. See Marvin A. Sweeney, TANAK: A Theological and Critical Introduction to the Jewish Bible (Minneapolis: Fortress Press, 2012), 365; Eugene H. Merrill, argues that Malachi's work preceded Ezra. See Eugene H. Merrill, Haggai, Zechariah and Malachi: An Exegetical Commentary (Chicago: Moody Press, 1994), 377-78; Blenkinsopp dates the book between 486 and 445 B.C.E.. See Blenkinsopp, History of Prophecy, 209); and Douglas Stuart dates the ministry of Malachi in the course of or marginally ahead of the reforms of Ezra and Nehemiah. See Douglas Stuart, "Malachi," in The Minor Prophets: An Exegetical and Expository Commentary (vol. 3; ed. Thomas E. McComiskey; Grand Rapids: Baker Books, 1998), 1245-1396 (1252-53).

32 See E. Ray Clendenen, "Malachi," in Haggai, Malachi (ed. Richard A. Taylor and E. Ray Clendenen; NAC 21A; Nashville, Tenn.: Broadman and Holman Publishers, 2004), 203-464 (206); Hill, Malachi, 83.

33 For a comprehensive treatment of the population and lived situation in the province of Yehud of the massive Persian Empire, the following sources can be helpful: Charles Carter, "The Province of Yehud in the Post-Exilic Period: Surrounding Site Distribution and Demography" in Temple and Community in the Persian Period (vol. 2 of Second Temple Studies; ed. Eskenazi C. Tamara and Richards, H. Kent, JSOTSup 175; Sheffield: JSOT Press, 1994), 106-145; Oded Lipschits, "Demographic Changes in Judah between the Seventh and Fifth Centuries B.C.E.," in Judah and the Judeans in the Neo-Babylonian Period (ed. Oded Lipschits and Joseph Blenkinsopp; Winona Lake, Ind.: Eisenbranus, 2003), 323-376; Oded Lipschits, The Fall and Rise of Jerusalem: Judah under Babylonian Rule (Winona Lake, Ind.: Eisenbranus, 2005), 261271; John Kessler, "Images of Exile: Representations of the 'Exile' and 'Empty Land' in Sixth to Fourth Century B.C.E. Yehudite Literature," in The Concept of Exile in Ancient Israel and Its Historical Contexts (ed. Ehud Ben Zvi and Christopher Levin; BZAW 404; Berlin: Walter de Gruyter, 2010), 309-351; Kyong-Jin Lee, The Authority and Authorization of the Torah in the Persian Period (CBET 64; Leuven: Peeters, 2011), 163. 
cive for growth and innovative economic policy, the Persian rule provides the background against which Malachi, a subject of the Persian king, must be assessed.

Thus like the rest the prophetic books, the book of Malachi is rooted within the framework of the environmental circumstances of the prophet's period. The book's perspective of lived reality divides the prophet's audience into various groups. ${ }^{34}$ The chosen people were still a colonial people in the Persian Empire. While there was relative peace in Malachi's world, it was not particularly happy moment for the Judean population. In this period of international tranquillity, Israel had little sense of vitality, direction as there was collapse of internal discipline. Depression and discontent were the prevailing feelings in Malachi's day. The expectations of preceding generation had crashed on the rock of reality. Those who had hoped for the establishment of a new international order following the restoration of the temple (Hag 2:7, 9, 1819; Ezek 43:1-5) and kingdom promises made to David (Ezek 34:13, 23-24), were sadly disappointed as these promises remained unrealised. The people had inherited hopelessness which could not equip them to adequately cope with the gloomy and seemingly unchanged world in which they now found themselves. In the cultic department the situation culminated in the superficial and heartless performance of duty. The altar of Yahweh was disregarded (Mal 1:6-8, 13), vows were offhandedly fulfilled (Mal 1:14), justice was perverted (Mal 2:6-9; $3: 5)^{35}$ and hypocrisy took place in the area of tithes and offerings (Mal 3:612). ${ }^{36}$ More than any other prophets, Malachi indict the priests and people and expose them to themselves. ${ }^{37}$

His generation, like that of Haggai and Zechariah, faced harsh and serious economic situations and lived in an atmosphere that was unenthusiastic for

34 Lena-Sofia Tiemeyer identifies the audience of Malachi to be the priests and the people. See Lena-Sofia Tiemeyer, "Giving a Voice to Malachi's Interlocutors," SJOT 19/2 (2005): 173-192 (178-78). See also, Peter Ross Bedford, "Discerning the Time: Haggai, Zechariah and the Delay in the Rebuilding of the Jerusalem Temple," in The Pitcher is Broken: Memorial Essays for Gosta W. Ahlstrom (ed. Steven W. Holloway and Lowell K. Handy; Sheffield: Sheffield Academic Press, 1995), 71-94 (72); Mark J. Boda, "Perspectives on Priest in Haggai-Malachi," in Prayer and Poetry in the Dead Sea Scrolls and Related Literature: Essays in honor of Eileen Schuller on the occasion of her 65th birthday (ed. Jeremy Penner, Ken M. Penner and Cecilia Wassen; STDJ 98; Brill: Leiden, 2012), 13-33 (15).

35 Blessing O. Bọlojẹ and Alphonso Groenewald, "Malachi's Concern for Social Justice: Malachi 2:17 and 3:5 and its Ethical Imperatives for Faith Communities," HTS 70/1 (2014); Art. \#2072, 9 pages (here p. 3). DOI: 10.4102/ hts.v70i1.2072.

36 Blessing O. Bọlojẹ and Alphonso Groenewald, "Hypocrisy in Stewardship: An Ethical Reading of Malachi 3:6-12 in the Context of Christian Stewardship," HTS 70/1 (2014); Art. \#2086, 11 pages (here pp. 2-3). DOI: 10.4102/hts.v70i1.2086.

37 Glazier-McDonald, Malachi, 17. 
Boloje and Groenewald, "Literary Analysis," OTE 28/2 (2015): 257-282 265

the practice of orthodoxy. ${ }^{38}$ The moral principles were abandoned for a series of ethical compromise, in which case personal success and benefits are principle standards for decision making. ${ }^{39}$ This was clearly manifest in a positive attitude towards intermarriage with foreign women and the growing prevalence of divorce that undermined ancient traditions. The ruined lives, the collapse of hopes, and the loss of faithfulness make it an abomination to Yahweh (Mal $2: 10-16) .{ }^{40}$ Malachi was thus faced with a wall of indifference and apathy. He interprets their thoughts, puts them in the abrupt, naked language and pictures them as protest to every charge brought against them. He spoke of the esteemed faith to a people for whom religion had become a routine and who were apathetic in their observance of cherished ancient traditions. Malachi's task was that of strengthening his people and this was obviously not a simple one in view of the fact that the prophetic promises of the prosperity of the land after the temple had been reconstructed had failed to manifest. His major concern was to correct the wrong view about the covenant relationship with Yahweh that had developed following the failure of the promises of the earlier prophets. As affirmed by Malachi, the loving relationship between Israel and Yahweh is a covenant condition not a covenant cost. He sought therefore, to dispute orientation based on cause and effect theology. ${ }^{41}$ Indeed, he enforces the claims of the law, but only to the extent that its forms are an expression of that spirit. Malachi's style of disputation with his audience no doubt helps one to appreciate the different and distinctive concerns of the book.

\section{LITERARY STYLE, STRUCTURE AND THEME}

Scholars have generally noted that what is distinctive about the book of Malachi is its literary style. ${ }^{42}$ It could be that on account of the cynicism and disappointment of the people and consequently lack of respect for their covenant with Yahweh, Malachi utilises an appealing technique in his attempt to bring Yahweh's concern to the people. Several labels have been given to the literary style with which he communicates with his audience: disputation, ${ }^{43}$ covenant

\footnotetext{
38 Assis, "Structure and Meaning," 356.

39 Craigie, Twelve, 244.

40 Blessing O. Bọloje and Alphonso Groenewald, "Marriage and Divorce in Malachi 2:10-16: An Ethical Reading of the Abomination to Yahweh for Faith Communities," VEccl 35/1 (2014c); Art. \#886, 10 pages. DOI: 10.4102/ve.v35i1.886.

41 See Boloje and Groenewald, "Marriage and Divorce in Malachi 2:10-16."

42 See Clendenen, "Malachi," 218; Glazier-McDonald, Malachi, 18.

43 Whether the disputation was rooted in some actual social context of dialogue and debate, or whether it is merely a literary form to communicate a message, remains uncertain, although the latter is most probably the case. Craigie, Twelve, 227. See also, Elizabeth Achtemeier, Nahum - Malachi (Atlanta: John Knox, 1986), 172; Clendenen, "Malachi," 219.
} 
lawsuit, ${ }^{44}$ confrontational dialogue, ${ }^{45}$ and catechetical format. ${ }^{46}$ It is noted that the question and answer technique used by Malachi in order to articulate his message is particularly noteworthy because of its rationalised, didactic cast. It is a pattern that is strictly followed in all the six oracle units making up the prophecy, and serves to make crystal clear what exactly the failure of the people is and why they continue to undergo the punishments looming upon them as covenant breakers. ${ }^{47}$ Although Malachi was not the first to utilise this question and answer technique, ${ }^{48}$ the question and answer schema is more extensive in Malachi than any other OT documents.

As one deeply involved in his community and obviously affected by what he experienced, Malachi confronted immediate community circumstances and the community in turn, disheartened, resentful, and doubtful reacted by questioning all that he said. This indeed enables one to see prophetic process at work. ${ }^{49}$ Regardless of whatever characterisation that one gives to the oracles of Malachi, almost all scholars are unanimous on the division of the book into six distinct oracles, a superscription and an epilogue. ${ }^{50}$ The epilogue (Mal 3:22-24 [MT] 4:4-6 [ET]), as some has argued consists of two separate appendices (Mal 3:22 [MT] 4:4 [ЕT] and 3:23-24[MT] 4:5-6 [ЕT]) generally regarded to be a later redactional addition. ${ }^{51}$ The book's six distinct oracles are structured in various forms: speech format, ${ }^{52}$ dialogue framework, ${ }^{53}$ concentric outline, ${ }^{54}$ chiastic

44 While Julia O'Brien offered other classifications, she discusses the possibility that the book employs the form of covenant lawsuit. See Julia M. O'Brien, Priest and Levite in Malachi (SBLDS 121; Atlanta: Scholars, 1990), 47-63; 63-80. See also, Michael H. Floyd, Minor Prophets (vol. 2; Grand Rapids: Eerdemans / Baker Books, 2000), 564-568.

45 John D. Hendrix, "You Say": Confrontation Dialogue in Malachi," RevExp 84 (1987): 465-477 (465).

46 Mark J. Boda, "Haggai: Master Rhetorician,” TynBul 51/2 (2000): 295-304 (299300); Glazier-McDonald, Malachi, 19.

47 Glazier-McDonald, Malachi, 19.

48 Several examples are found scattered throughout the OT, cf. Deut 29:23f.; $1 \mathrm{Kgs}$ 9:8-9; Amos 5:18; Jer 13:12f.; 15:1f.; 22:8-9; Hag 1:9f.; 2:10f.; Ezek 11:2f; 18:19; Isa 49:11; 50:1f. Schuller, "Malachi," 850; Glazier-McDonald, Malachi, 21.

49 Indeed, Glazier-McDonald notes, "Prophecy was not only the response of the prophet to the questions posed by his society and time; it was also the questioning of that society by its incisive prophetic critique." Glazier-McDonald, Malachi, 22-23.

50 See for example, Assis, "Structure and Meaning," 356; Clendenen, "Malachi," 227; Hill, Malachi, 26.

51 Glazier-McDonald, Malachi, 243-245; Floyd, Minor Prophets 2, 568-69; Elie Assis, "Moses, Elijah and the Messianic Hope: A New Reading of Malachi 3:22-24," ZAW 123/2 (2011): 207-220 (208-209). Cited 6 February 2015. DOI: 10.1515/ZAW .2011 .013 .

52 Yahweh's love: 1:2-5; unfaithful priests: 1:6-2:9; marriage with foreign women and divorce: 2:10-16; the justice of Yahweh: 2:17-3:5; deception in the bringing of tithes and offerings: $3: 6-12$; the day of judgement: $3: 13-4: 3$; Torah observance: $4: 4$ 
pattern, ${ }^{55}$ parenetic speech to the clergy and people inviting them to show adequate respect for Yahweh. ${ }^{56}$ The various oracles present disputations of the prophet on behalf of Yahweh with the people. Each oracle contains a claim of the people that is closely refuted by the prophet. Of interest is the fact that there are no recognisable formulae indicating the opening or closing of any of the oracles. The divisions are thus based on thematic distinctions only. ${ }^{57}$

Although the diversity of thematic connections have been noted within the Book of the Twelve, "the principal themes of the whole book are those of covenant-election, fidelity and infidelity, fertility and infertility, turning and returning, justice of God and mercy of God, the kingship of God, the place of his dwelling (Temple/Mt. Zion), the nations as enemies, the nations as allies." The book of Malachi emphasises a number of primary as well as other secondary theological ideas. While one may find it difficult to contend that one essential theme summarises the entire message of the book, ${ }^{60}$ thematic ideas that are noticeable in the book of Malachi includes the unifying theme of the Day of Yahweh, ${ }^{61}$ found in the book of the Twelve including covenant, temple worship and ministerial integrity, and the concern for justice. ${ }^{62}$ These primary themes in Malachi's message are used by the prophet to challenge his people to identify

(first appendix); the coming of Elijah: 4:5-6 (second appendix). Clendenen, "Malachi," 227.

53 David J. Clark and Howard A. Hatton, A Handbook on Haggai, Zechariah and Malachi (New York: United Bible Societies, 2002), 370.

54 Gordon P. Hugenberger, Marriage as a Covenant: Biblical Law and Ethics Governing Marriage Developed from the Perspective of Malachi (VTSup 52; Leinen: Brill, 1994), 24-25.

55 David A. Dorsey, The Literary Structure of the Old Testament: A Commentary on Genesis to Malachi (Grand Rapids: Baker Book House, 1999), 323.

56 Sweeney, TANAK, 366.

57 Assis, "Structure and Meaning," 357.

58 See for example, Terence Collins, The Mantle of Elijah: The Redaction Criticism of the Prophetic Books (BibSem 20; Sheffield: Sheffield Academic Press, 1993), 65; Paul L. Redditt, "Themes in Haggai-Zechariah-Malachi," Int 61 (2007): 184-197 (184, 188-195); James D. Nogalski, "Recurring Themes in the Book of the Twelve: Creating Points of Contact for a Theological Reading," Int 61/2 (2007): 125-136 (125).

59 LeCureux, Thematic Unity, 16.

60 Ralph L. Smith, "The Shape of Theology in the Book of Malachi," SJOT 30/1 (1987): 22-27 (24).

61 Rolf Rendtorff, "How to Read the Book of the Twelve as a Theological Unity," in Reading and Hearing the Book of the Twelve (ed. James D. Nogalski and Marvin A. Sweeney; SBLSymS 15; Atlanta: Society of Biblical Literature, 2000), 75-87; Boloje and Groenewald, "Malachi's Eschatological Day," 53-81.

62 For an extended treatment of these themes, see the first author's doctoral thesis. Blessing O. Boloje, "Malachi's View on Temple Rituals and its Ethical Implications," (Ph.D. thesis; Pretoria: University of Pretoria, 2014), 141-161. 
and put into practice the ethical requirements of their covenant relationship with Yahweh. These themes have no doubt, mapped out the book as a literary masterpiece with unbiased conformity with the thematic thread of the Book of the Twelve. In the following sections the theme of covenant in the book of Malachi is placed in perspective.

\section{ANALYSIS OF COVENANT THEMES IN MALACHI}

The key concepts of the prophets of the Second Temple or post-exilic era provided an alternative perspective on the catastrophe of destruction and exile. It includes the renewal of Israel, return and restoration, and renewal of covenant with Yahweh. Malachi's mission was that of reinforcing his people's belief and confidence in Yahweh and reminding them of their responsibilities as members of covenant community with Yahweh. Indeed the concept of the Covenant of Israel is fundamental to Malachi's message. It is a dominant theme in the book. ${ }^{63}$ From a theological stand point, the essential components of this Second Temple or post-exilic prophecy are the personhood of Yahweh - the God of Israel, Yahweh's covenant relationship with Israel, and the all pervasive message of unreserved and enthusiastic personal response of Israel to the truth assertions of the prophetic voice. ${ }^{64}$

The word $b^{e}$ rîth, from the Hebrew translated "covenant," has been defined as an elevated relationship of obligation under oath. ${ }^{65}$ John Lundquist considers it to be "a formal, ritually enacted ceremony mediated by the prophet or king in the temple, a ceremony in which the community is founded through the people's indexical acceptance of the revealed law."66 $b^{e}$ rîth "covenant" according to Kessler, has its origins in close relation to the concept of a "bond, fetter, or obligation" existing between two individuals or groups. "The concept of covenant does, generally speaking, denote some kind of solemn bond or link between two parties." Covenants were made in a variety of contexts: social, political, and religious. They could be arrangements between individuals, families, clans, or nations. They were generally not made between total strangers. But they served to solidify and regulate already existing, functional relationships (cf. Gen 21:22-34; 26:26-33; 31:43-55). They included oaths of various forms and of varying durations. ${ }^{67}$ Gary Knoppers, though defines covenant as "a formal agreement involving two parties," holds that covenant is a subject of a diversity of shapes in a diversity of historical contexts that defy adequate

63 Assis, "Structure and Meaning," 355; Redditt, Haggai, 156; Wallace and Mackenzie, "Covenant Themes," 558.

64 Hill, Malachi, 42.

65 Hugenberger, Marriage as a Covenant, 11.

66 John M. Lundquist, "Temple, Covenant, and Law in the Ancient Near East and in the Old Testament," in Israel's Apostasy and Restoration (ed. Avraham Gileadi; Grand Rapids: Baker Book House, 1988), 293-306 (295).

67 Kessler, Old Testament Theology, 179-180. 
definition. ${ }^{68}$ Richard Wells gives a definition of covenant that provides the individual an intimate fellowship in which Yahweh's presence is established in its entire dimension of the relationship along with commitment and obligations:

It is of course well-established that various legal, contractual agreements were known in the ancient world, and that many of the essential features of these covenants appear in various biblical contexts. However, the biblical covenant is not merely a legal device. . . . It is a legal transaction for which there is no analogy in the circle of experience precisely because it is not, strictly speaking, legal. It is personal and relational, as well as regulative, judicial, normative, and obligatory. ${ }^{69}$

While the meaning and function of $b^{e}$ rith may be complicated in the Bible, René Lopez notes:

When between men, it could mean treaty (as with Jacob and Laban in Genesis 31:44), constitution between official and subject (as with David and Abner in 2 Samuel 3:12-13, 21), pledge (as with Jehoiada and captains in 2 Kings 11:4), alliance of friendship (as with David and Jonathan in 1 Samuel 18:3), alliance of marriage (as in Malachi 2:14). When between God and man, it could mean alliance of friendship (as in Psalm 25:14) or covenant as a divine constitution or ordinance with signs or pledges (as in Genesis 9:9-17; Exodus 19:5). Sometimes God even makes a $b^{e}$ rîth with stones, beasts of the field (Job 5:23), and Leviathan (40:28). And Isaiah speaks of a $b^{e}$ rîth Israelites made with death. ${ }^{70}$

In the following sections, the implications of Yahweh's covenant love for Israel (Mal 1:2-5) is examined along with the three clear references to covenant in the book of Malachi: the levitical covenant (Mal 2:4, 8), the covenant of our fathers (Mal 2:10) and the marriage covenant (Mal 2:14).

\section{Yahweh's Covenant Love for Israel}

Of Malachi's several terminologies that are associated with the key concept of covenant is 'ahabh ("love"). Malachi's first disputation begins with a short, but significant statement: "I have loved you, says the Lord" (1:2). The word 'ahabh occurs three times in Mal 1:2. It equals that of Zechariah and stands as the most frequently used term in the book of the Twelve with the exception of Hosea. The use of the word, grounded in Deuteronomy, conveys the idea of covenant love, in addition to the overall idea of election, since Israel was chosen by

68 Knoppers, “Ancient Near Eastern,” 696, 695-696.

69 Richard C. Wells, "The Subtle Crises of Secularism: Preaching the Burden of Israel," CTR 2/1 (1987): 39-61 (45).

70 René Lopez, "Israelite Covenants in the Light of Ancient Near Eastern Covenants," CTSJ 9/2 (2003): 92-111 (103). 
Yahweh (Deut 7:8) as against Edom. ${ }^{71}$ While this statement receives no further explanation, it summarises Israel's entire history of Covenant. ${ }^{72}$ If one considers covenant as always at Yahweh's order and on his initiative, then the ethos of the covenant will be an ethos of grace. ${ }^{73}$

The relationship between Yahweh and Israel that was sealed by covenant at Sinai following Yahweh's great deliverance at the Red Sea is expressed by the Sinai Covenant Theology. Yahweh's covenant relationship with Israel at Sinai constitutes the theological centre of the body of OT literature described as Deuteronomic (or Deuteronomistic) expressed basically in the books of Deuteronomy and Joshua through 2 Kings, as well as in certain prophetic books and psalms. The making of the covenant is also described in Exod 19-24 and 32-34, although the language of these passages differs from that of Deuteronomy. ${ }^{74}$ The phrase, "Keeping Yahweh's commandments, statutes, and ordinances" (Deut 6:1, 3, cf. Deut 4:23; 5:1, 22; 6:3-4; 7:11-12) stresses Israel's ongoing responsibility to live in faithfulness to the terms of the covenant in order to continue to enjoy its benefits and to maintain the nations' relationship with Yahweh in good order. ${ }^{75}$ Thus, Israel understood that, should they violate the covenant, the nation could be visited with variety of misfortunes, even complete destruction (Deut 6:15; 7:4; 9:8, 19; 28:58-68). Prophetic preaching in the OT is saturated with language concerning Israel's covenantal duties and consequences of covenant violation. This is why the prophets are sometimes referred to as "covenant enforcers.",76

The precise formula that summarises covenant theology in the OT, "I will be your God, and you will be my people," emphases Yahweh's volition in the relationship, not Israel. The invitation to a covenant is grounded on the great divine acts of the past which Israel has herself experienced; a relationship that is better referred to as election. ${ }^{77}$ While the dating of the election tradition has extensively engrossed scholarly dialogue, Israel is Yahweh's nakhala ("inheritance" Deut 4:20; 9:26), segulla ("possession" or "property" Deut 7:6; 14:2; 26:18; cf. Mal 3:17), a word used to describe Israel as Yahweh's people, and khelaq ("portion" Deut 32:9), all of which imply divine election. ${ }^{78}$ A parade presentation of the doctrine of Yahweh's election of Israel is seen in Deut 26, and its core in Deut 7:6. Yahweh's love for Israel caused him to act unilaterally in choosing Israel to be his people (Deut $1: 31 ; 7: 8 ; 14: 1-2$ ). The greatest demonstration of that election was their deliverance from Egypt and

71 LeCureux, Thematic Unity, 209.

72 Craigie, Twelve, 227; Assis, "Structure and Meaning," 355, 363.

73 Miller, Covenant and Grace, 203.

74 Kessler, Old Testament Theology, 196-198.

75 Kessler, Old Testament Theology, 199.

76 Kessler, Old Testament Theology, 225.

77 Miller, Covenant and Grace, 194.

78 Miller, Covenant and Grace, 196-97. 
Boloje and Groenewald, "Literary Analysis," OTE 28/2 (2015): 257-282 271

initiation of a covenant with them (Mic 6:1-8; Jer 2). Thus the doctrine of election finds its most concrete expression in the OT language of covenant. ${ }^{79}$ Yahweh's pronouncement of love toward Israel constitutes the basic foundation of everything Malachi had to say in criticism of Israel subsequent to this declaration of love. ${ }^{80}$ This declaration of Yahweh's covenant love echoes the words of the prophet Hosea $(3: 1 ; 11: 1 ; 14: 5)$. In Hosea, the word conveys the image of unfaithfulness, used in the context of Israel chasing other lovers (2:2f.). He declares Yahweh's covenant love for his people despite their unfaithfulness (3:1). While Hosea uses the terminology of the Exodus narrative to illustrate Yahweh's compassion for Israel, Malachi utilises the traditions concerning Isaac's two sons (Gen 25:19-34; 27:1-45; 32:1-33).

The prophet employs the language of love and hatred to set God's preferential love and kindness toward Israel in quick relief. ${ }^{81}$ However, Malachi's interlocutors' shocking question, "How have you loved us?" stands at the background of what is perceived to be unrealised expectations of Yahweh's promised restoration and love. Their response indicates that they had long heard these promises of love, but had witnessed little manifestation of it in their lives. What Malachi offers as evidence of Yahweh's love is the current and existing situation of Edom. ${ }^{82}$ While by Malachi's time, Edom had been desolated, Edom's "just-deserts" for Malachi represent clear evidence of Yahweh's covenantal love for Israel. ${ }^{83}$ It must be noted too that while Malachi's assertion of Yahweh's exclusive covenant love for Israel is made in the midst of an internal dispute; he hopes to persuade his people Israel to give due glory and honour to Yahweh who freely extends mercy with unconditional love and whose magnificence extends far beyond territorial limits (Mal 1:5). ${ }^{84}$

\section{Yahweh's Covenant with Levi (berîth hallēwî)}

Yahweh's covenant with Levi (Mal 2:8) falls within the second oracle (Mal 1:6-2:9) that has been named, "Priests and God argue about respect." ${ }^{\text {" }}$ This extensive section is filled with harsh criticisms of worship as it was conducted in Malachi's day. At its centre is Yahweh's concern with the priests and their

\footnotetext{
79 Miller, Covenant and Grace, 197.

80 William P. Brown, Obadiah through Malachi (Louisville; Ky.; Westminster John Knox Press, 1996), 193.

81 Brown, Obadiah, 193.

82 LeCureux notes that Edom occupies a peculiar place of hatred in the writers of the Twelve, occurring 9 times in the Book (Joel 4:19; Amos 1:6, 9, 11; 2:1; 9:12; Obad 1:11; Mal 1:4). While the prospect of restoration is still on the lips of Edom's survivors (Mal 1:4), Malachi declares that this will never come to manifestation. LeCureux, Thematic Unity, 210-211.

83 Brown, Obadiah, 193.

84 Brown, Obadiah, 194.

85 Julia M. O’Brien, Nahum, Habakkuk, Zephaniah, Haggai, Zechariah, Malachi (ed. Patrick D. Miller; AOTC; Nashville: Abingdon Press, 2004), 286.
} 
offerings. While Yahweh's contempt for the priesthood is repeated throughout the unit $(1: 6,10 ; 2: 1-2,3)$, and his disapproval with their imperfect, blemished and defiled offerings noticeable $(1: 7-8,9-11,12-14)$, the cause of his anger shifts from the precise issue of covenant sacrifice to the wider failings of the priests as keepers and instruction of the covenant (2:7-9). ${ }^{86}$

The underlying and cohesive idea of this oracle is the violation of Yahweh's covenant with Levi ( $b^{e}$ rîth 'eth-lêwî "my covenant with Levi" 2:4 and $b^{e}$ rîth hallêwî "covenant of Levi" 2:8). These are phrases which seem to lack any direct historical allusion. As observed by Hill, the Bible nowhere records the establishment of this covenant between Yahweh and Levi, the eponymous ancestor of the Levitical priesthood. ${ }^{87}$ However, commentators have argued over the probable historical settings of Malachi's reference, in the long run proposing two pentateuchal locations and one from the prophets (Num 25:1113; Deut 33:8-11; Jer 33:20-21) ${ }^{88}$ That Malachi calls this covenant Levitical rather than Aaronic (via Phinehas) stems from the aforementioned subordination of the priesthood to the house of Levi." 89 Contrarily, in their attempt to look for the origins of Malachi's reference to the covenant of Levi, Wallace and Mackenzie discard the pentateuchal allusion to Number 25:11-13, believed to be Yahweh's covenant with Aaron (via Phinehas); Deuteronomy 33:8-11 that indicates Yahweh's compact with Israel as a whole and where the obligations of the Levites to Moses' Torah are explained; and opt for more possible link with Deut 28:1-2, 15 and Leviticus 26:3, 14-32 in the light of the provisional curses' formula reflected in Malachi $(2: 2-3) .^{90}$

Following Glazier-McDonald in connection to Numbers' allusion of Malachi's reference to the covenant of Levi, an expanded explanation needs to be provided such that encompasses the broader understanding of the priestly obedience demonstrated by the priestly duties listed in Numbers and reflected by Malachi. While the responsibilities of the Levites are not examined specifically with the term "covenant," their role and responsibilities are made very explicit in Numbers 3-4. ${ }^{91}$ Although it is difficult to create a distinction between priests and Levi/sons of Levi (kōhănîm and $l \bar{e} w \hat{\imath} / b^{e}$ nê-êtî) both priests and Levites have the same responsibilities of altar functions and proper pedagogical instruction. The distinction then is not of function but that of attitude. Malachi constructs a levite-cohen model in which the levite represents the ancient and idealised priestly class while the cohen personifies the contempo-

86 LeCureux, Thematic Unity, 214.

87 Hill, Malachi, 206.

88 LeCureux, Thematic Unity, 214.

89 In her examination of verbal parallels, Glazier-McDonald suggests that Num 25:11-13 forms at least part of the background for Malachi's reference. ". . . it may be posited that Mal 2:4-5 is based on Num 25:12f." Glazier-McDonald, Malachi, 79-80.

90 Wallace and Mackenzie, "Covenant Themes," 550-51.

91 LeCureux, Thematic Unity, 215. 
Boloje and Groenewald, "Literary Analysis," OTE 28/2 (2015): 257-282 273

rary degenerate clergy. ${ }^{92}$ In this regards, the relationship between the Levi as a personified figure and Yahweh is illustrated in the form of covenant relationship. Malachi thus describes their mutual identity and corporate obligation, in addition to their culpability under the covenantal relationship they have with Yahweh. ${ }^{93}$

While up to this point, Malachi has criticised the priests with great rhetorical flair for their malpractices in the cultic rituals, when describing the idyllic levite-priest, his emphasis on sacrifice is incorporated into the wider role of Torah instruction. As Stuart notes:

Three principal elements that constitute what a priest who truly fears God is supposed to be like: (1) truthful and accurate teaching on the law and rendering of legal decisions ('true law was in his mouth and no iniquity was found on his lips'), (2) full and consistent obedience in various tasks ('perfectly and consistently he served me'), and (3) preservation of the holiness of God's people ('and he turned many from sin'). ${ }^{94}$

The priests have been unfaithful to their covenant. Their violations of these covenant ideals and the coming covenant curses (2:1-3) become the basic concerns of the second oracle (Mal 1:6-2:9).

\section{Covenant of our Fathers (berîth 'ăbhōthênû)}

Following his expression of judgement against the priests, Malachi immediately appeals to all Israelites by calling attention to their common covenantal heritage. The interrogative question in Mal 2:10, ${ }^{95}$ presents a remarkable and mutual self-indictment. Why it is difficult to determine what could have constituted the exact origin and remarkable ancestor of the "covenant of our fathers," and philosophy of equality between all people and nations. Everyone is an offspring of one single man, and as a result everyone is equal. Here, the covenant

92 LeCureux, Thematic Unity, 215. See also, Lena-Sofia Tiemeyer, Priestly Rites and Prophetic Rage: Post-exilic Prophetic Critique of the Priesthood (FAT 2/19; Tubingen: Mohr Siebeck, 2006), 129.

93 Stuart, "Malachi," 1314-1315.

94 Stuart, "Malachi," 1320.

95 "Do we not all have one father? Has not one God created us? Why do we deal treacherously each against his brother so as to profane the covenant of our fathers?" (NASV).

96 Wallace and Mackenzie hold that in Malachi, 'ăbhōthênu (our fathers) could have been the Sinai/Horeb generation and that the text could be intentionally uncertain, in light of all the covenants indicated as proxy to the initial Yahweh's covenant election of Israel as a nation. Wallace and Mackenzie, "Covenant Themes," 551-552. 
they referred to is the feeling of brotherhood and equality between all people. In their estimation, it is this covenant that is being violated. ${ }^{97}$

The interrogative question lunches the allegation against the people for their infidelity and treachery against fellow covenant members. Such unfaithfulness is regarded to be violation and contempt for Israel's covenant relationship with Yahweh, in the same manner the behaviour of the priests was violating and disregarding the Yahweh's covenant with Levi (2:8). Consequently, the infringement of these remarkable communal, mutual and shared obligations of covenant relationship that is, the failure to love fellow covenant members resulted in the infringement of their sacred obligation namely; lethargy in their love for Yahweh. ${ }^{98}$ The wider concern of this passage then, is the importance of faithfulness in all forms relationship, both with fellow human beings and with Yahweh. Faithfulness in all relationships is a part of the mortal that holds a human society together. For Israel, faithfulness toward Yahweh, reflecting his initial faithfulness, was the essential foundation upon which the very fabric of all human relationships could be established. ${ }^{99}$ This fabric was broken in Malachi and the ideological consequence was treachery to one another and unfaithfulness to Yahweh, at the same time.

\section{The Covenant of Marriage}

The fundamental theological motif that starts and end this passage (Mal 2:10$16)^{100}$ is the one God who created all human beings, who was known to his people in a relationship characterised by faithfulness (Mal 2:10). This one God requires faithful unity in marriage (2:14-16). In this unit, Malachi consistently roots the covenantal sacredness of marriage in the very unity of Yahweh. This high regard for marriage is seen as an expression of commitment to the covenant, the same idea used to describe Israel's national life, in the same way the covenant of marriage rest at the heart of its social life. ${ }^{101}$ Consequently, to break the bond of marriage is to disregard the marriage covenant (Mal 2:14) while at the same time making the covenant irrelevant. This ultimately shatters

\footnotetext{
97 Assis, "Structure and Meaning," 360.

98 Clendenen, "Malachi," 326.

99 Craigie, Twelve, 238.

100 Several interpretations have been given to this passage by different commentators. While some propose a literal interpretation that is concerned with marriages to foreign women in the post-exilic community, others opt for a figurative interpretation, one that refers to idolatry. See for example, Hugenberger, Marriage as a Covenant, 339; Julia M. O'Brien, “Judah as Wife and Husband: Deconstructing Gender in Malachi," JBL 115/2 (1996): 241-250 (244, 249); Graham S. Ogden, "The Use of Figurative Language in Malachi 2:10-16," BT 39 (1988): 223-230; David L. Petersen, Zechariah 9-14 and Malachi: A Commentary (Louisville: Westminster John Knox, 1995), 198200.

101 Craigie, Twelve, 236.
} 
the mutual and communal identity of Israel that is distinctively rooted in the Creator. $^{102}$

In Malachi's time, the sanctity of marriage seems to have been grossly compromised, and with it was a massive increase in divorce and remarriages. It was a crisis that threatens to destroy the singular uniqueness of Israel, namely its identity as a chosen people under pagan domination. Malachi's concern was not just one of Jewish men marrying pagan women, but also that of divorcing their Jewish wives "by covenant" in preference of foreign wives. Malachi sets the gravity of this covenant violation side by side divorce and violence (Mal 2:16). From Malachi human and theological point of view, to break such a bond of unity is a rejection of the oneness of Yahweh's gracious and commanding nature. Infidelity to one's spouse constitutes nothing less than a violation of Yahweh's commandment, a violation that unavoidably makes its route to Yahweh's altar (Mal 2:13-14). ${ }^{103}$ Those who could so quickly abandon the covenant of marriage for personal gain could also quickly abandon their covenant relationship with Yahweh. These again are both acts of unfaithfulness. ${ }^{104}$

\section{E THEOLOGICAL SYNTHESIS AND CONCLUSION}

What positive theological content is there to this theme of covenant? From the above analysis, it clear that the theme of covenant dominates in all the first three oracles and there is a connection between these oracles and the last three. The first oracle - salvation oracle $(1: 2-5)$ reflects a crisis in the covenantal relationship between Yahweh and Israel. This oracle is vitally connected with the third oracle - speech of exhortation (2:10-16), in which Judean men are criticised for violating their marriage covenant with their Jewish wives (2:11, 14-16), and for adopting a universal ideology of covenant between all humans $(2: 10) .{ }^{105}$ In the second oracle $(1: 6-2: 9)$, Yahweh is faithful and the priests are not; they have failed to conduct the sacrificial cult in accordance with the institutional requirements just because of the fact that they have corrupted the Levitical covenant $(2: 5,8)$. As the second oracle in the first part of the book of Malachi, this oracle deals with the sacrificial cult and it is vitally connected with the fifth oracle that stands at the middle of the last three oracles. As Stuart notes, the issues at the heart of the fifth oracle are certainly related to those of the fourth (and second and third as well) disputation, but the connection of 3:67 to $2: 17-3: 5$ is a matter of topic rather than form. ${ }^{106}$ The subject matter of the fifth oracle (3:7-12) is the cultic ritual. In these two cultic oracles, Malachi's accusations against the priests and the people are similar. "In both, the argument is that they do not properly observe a religious precept, sacrifices or

102 Brown, Obadiah, 199.

103 Brown, Obadiah, 199.

104 Clendenen, "Malachi," 342.

105 Assis, "Structure and Meaning," 363.

106 Stuart, "Malachi," 1361. 
tithes." ${ }^{107}$ However, a connection exists between the fifth oracle and the fourth and sixth oracles: they all deal with the concept of Yahweh's justice. The fourth oracle (2:17-3:6), from the perspective of the people deals with Yahweh's failure to judge evildoers and sixth oracle (3:13-21) resumes the topic which was basic in 2:17-3:6 namely, Yahweh's ability to judge evildoers. In their opinion, it is profitless to worship Yahweh, since the wicked prosper while the righteous suffer. These two are on a conjectural level while the fifth oracle serves as an application of Yahweh's justice in relation to ritual. ${ }^{108}$

Malachi's interlocutors have expressed misgivings regarding Yahweh's faithfulness to them as covenant partner in need. Malachi responded by expounding the history of Esau/Edom in the past, present and future, which shows Yahweh's unconditional commitment and faithfulness to Israel forevermore. Yahweh's commitment to his people through the covenant is further stressed: "For I, the LORD, do not change; therefore you, O sons of Jacob, are not consumed" (3:6 NASV). The verse serves as appropriate transition verse, establishing both judgement and blessing in Yahweh's unfailing character. Malachi's affirmation that Yahweh has not changed should not be regarded primarily as a metaphysical statement, a theological commentary on the nature of Yahweh's being. Rather, the prophet's attests to Yahweh's faithfulness to his covenant agreement with Israel. Yahweh has not changed the agreement, but has remained committed and faithful to his oath of loyalty. The corollary to Yahweh's unchanging nature is the perpetual preservation of Israel. ${ }^{109}$ Yahweh's endurance with a covenant-breaking Israel is also demonstrated in Malachi 3:7. Here Israel is considered guilty of covenant violation, a disappointment that is compounded by the contrast of Yahweh's previously stated covenant fidelity (3:6). By mentioning the name of their forefathers, Malachi equates the present condition of his interlocutors with those of their pre-exilic, unfaithful covenant violating fathers.

The moral force behind Malachi's accusations against the nation is grounded upon Yahweh's unchangeable character. From a theological abstraction, Yahweh's changelessness is cast in terms of its effects, namely the call to moral integrity and acceptable worship is a call to steadfast fidelity in practice. An inversion of justice, whereby the wicked prosper, gave rise to the question of where Yahweh is in the face of moral contradiction. Where the laments of the psalmists and prophets worked hand in hand to relieve the problem of human suffering, Malachi finds only deep-rooted cynicism behind the complaints of the priests and people. Both the priests and people, subject Yahweh to their tiresome complaints about Yahweh's governance over the world. From Malachi's point of view, their complaint of injustice is the height of hypocrisy: they are benefiting from new sexual relationships $(2: 11,14-16)$, from negligent

\footnotetext{
107 Stuart, "Malachi," 361.

108 Stuart, "Malachi," 361.

109 LeCureux, Thematic Unity, 218-219.
} 
priestly standards (1:7-14), and from showing favouritism in judgement (2:69). ${ }^{110}$

In the face of declining and distressing situations arising from the violation of their covenant relationship with Yahweh, Malachi clearly puts together a logical, comprehensible and justifiable defence for Yahweh's justice and sovereignty, which makes plain the necessity of the advent of the messenger of the covenant and the inevitability of Yahweh's Day in which all of society shall be judged and transformed. ${ }^{111}$ The list of sins, spanning from religious to the social, integrates and overwhelmed the entire community life, whose centre is the very precincts of the one and only temple of the Lord of hosts. The effects of deceitful and false worship against which Malachi protested in 1:7-14 have overwhelmed the entire community. Like his prophetic predecessors, Malachi sees worship and justice as inseparably bound together. Thus worship is not true worship except it pursues justice for the widow, orphan, and foreigner (3:5). ${ }^{112}$ Yahweh's justice, although not currently manifest, will become visible in the future, and the people are particularly enjoined to faithfully observe the unique Israelite rituals embedded in their covenant relationship with Yahweh. To this end, it can be concluded, that covenant relationship, as the central and cohesive theological motif connecting and coordinating several themes in the book of Malachi as well as illuminating its message, is indeed a theological datum of substance.

\section{BIBLIOGRAPHY}

Achtemeier, Elizabeth. Nahum - Malachi. Atlanta: John Knox, 1986.

Anderson, George W. The History and Religion of Israel. Oxford: University Press, 1989.

Assis, Elie "Structure and Meaning in the Book of Malachi." Pages 354-369 in Prophecy and the Prophets in Ancient Israel: Proceedings of the Oxford Old Testament Seminar. Edited by John Day. Library of Hebrew Bible/Old Testament Studies 31. New York: T\&T Clark 2010.

."Moses, Elijah and the Messianic Hope: A New Reading of Malachi 3:2224." Zeitschrift für die Alttestamentliche Wissenschaft 123/2 (2011): 207-220. Cited 6 February 2015. DOI: 10.1515/ZAW.2011.013.

Badcock, Gary D. "God of the Covenant." Pages 67-84 in Covenant Theology. Edited by Mark J. Cartledge and David Mills. Waynesboro, Ga.: Paternoster Press, 2001.

Bedford, Peter Ross. "Discerning the Time: Haggai, Zechariah and the Delay in the Rebuilding of the Jerusalem Temple." Pages 71-94 in The Pitcher is Broken:

110 Brown, Obadiah, 200.

111 Stulman and Kim, You are My People, 243; Michael U. Udoekpo, Re-Thinking the Day of YHWH and the Restoration of Fortunes in the Prophet Zephaniah: An Exegetical and Theological Study of 1:14-18; 3:14-20 (Bern: Peter Lang AG, 2010), 275.

112 Brown, Obadiah, 201. 
278 Boloje and Groenewald, "Literary Analysis," OTE 28/2 (2015): 257-282

Memorial Essays for Gosta W. Ahlstrom. Edited by Steven W. Holloway and Lowell K. Handy. Sheffield: Sheffield Academic Press, 1995.

Blenkinsopp, Joseph. A History of Prophecy in Israel. Louisville: WJKP, 1996. Boda, Mark J. "Haggai: Master Rhetorician." Tyndale Bulletin 51/2 (2000): 295-304. . "Perspectives on Priest in Haggai-Malachi." Pages 13-33 in Prayer and

Poetry in the Dead Sea Scrolls and Related Literature. Essays in Honor of Eileen Schuller on the Occasion of her 65th birthday. Studies on the Texts of the Desert of Judah 98. Edited by Jeremy Penner, Ken M. Penner and Cecilia Wassen. Brill: Leiden, 2012.

Boloje, Blessing O. "Malachi's View on Temple Rituals and its Ethical Implications." Ph.D. thesis. Pretoria: University of Pretoria, 2014.

Boloje Blessing O. and Alphonso Groenewald. "Malachi's Eschatological Day of Yahweh: Its Dual Roles of Cultic Restoration and Enactment of Social Justice (Mal 3:1-5; 3:16-4:6)." Old Testament Essays 27/1 (2014): 53-81. ."Malachi's Concern for Social Justice: Malachi 2:17 And 3:5 and its Ethical Imperatives for Faith Communities." HTS Teologiese Studies/Theological Studies 70/1 (2014). Art. \#2072, 9 pages. DOI: 10.4102/hts.v70i1.2072. . "Hypocrisy in Stewardship: An Ethical Reading of Malachi 3:6-12 in the Context of Christian Stewardship." HTS Teologiese Studies/Theological Studies 70/1 (2014). Art. \#2086, 11 pages. DOI: DOI: 10.4102/hts.v70i1.2086. . "Marriage and Divorce in Malachi 2:10-16: An Ethical Reading of the Abomination to Yahweh for Faith Communities." Verbum et Ecclesia 35/1 (2014). Art. \#886, 10 pages. DOI : 10.4102/ve.v35i1.886.

Brown, William P. Obadiah through Malachi. Louisville; Ky.: Westminster John Knox Press, 1996.

Bruggemann, Walter. Theology of the Old Testament: Testimony, Dispute, Advocacy. Minneapolis: Fortress Press, 1997. 2005. Worship in Ancient Israel: An Essential Guide. Nashville: Abingdon Press,

Carter, Charles. "The Province of Yehud in the Post-Exilic Period: Surrounding Site Distribution and Demography." Pages 106-145 in Temple and Community in the Persian Period. Volume 2 of Second Temple Studies. Edited by Eskenazi C. Tamara and Richards H. Kent. Journal for the Study of Old Testament Supplement Series 175. Sheffield: JSOT Press, 1994.

Chisholm, Robert B. “A Theology of the Minor Prophets.” Pages 397-433 in Biblical Theology of the Old Testament. Edited by Roy B. Zuck. Chicago: Moody Press, 2002.

Clark, David J. and Howard A. Hatton. A Handbook on Haggai, Zechariah and Malachi. New York: United Bible Societies, 2002.

Clendenen, E. Ray. "Malachi." Pages 203-464 in Haggai, Malachi. Edited by Richard A. Taylor and E. Ray Clendenen. New American Commentary 21A. Nashville, Tenn.: Broadman and Holman Publishers.

Collins, Terence. The Mantle of Elijah: The Redaction Criticism of the Prophetic Books. The Biblical Seminar 20. Sheffield: Sheffield Academic Press, 1993.

Craigie, Peter C. The Twelve Prophets. Volume 2. The Daily Study Bible. Philadelphia: The Westminster Press, 1985.

Dentan, Robert C. “The Book of Malachi." Pages 1117-1144 in vol. 6 of The Interpreter's Bible. Edited by George A. Buttrick. Nashville: Abingdon, 1956. 
Boloje and Groenewald, "Literary Analysis," OTE 28/2 (2015): 257-282

Dorsey, David A. The Literary Structure of the Old Testament: A Commentary on Genesis to Malachi. Grand Rapids: Baker Book House, 1999.

Dumbrell, William J. "The Prospect of Unconditionality in the Sinaitic Covenant." Pages 141-155 in Israel's Apostasy and Restoration: Essays in Honor of Roland K. Harrison. Edited by Avraham Gileadi. Grand Rapids: Baker, 1988.

Eichrodt, Walther. Theology of the Old Testament. Volume 1. Philadelphia: Westminster, 1961.

Eissfeldt, Otto. The Old Testament: An Introduction. New York: Harper \& Row, 1965.

Floyd, Michael H. Minor Prophets. Volume 2. Grand Rapids: Eerdmans / Baker Books, 2000.

Gerstenberger, Erhard S. Israel in the Persian Period: The Fifth and Fourth Centuries B.C.E. Translated by S. S. Schatzmann. Atlanta: Society of Biblical Literature, 2011.

Gertz, Jan Christian, Angelika Berlejung, Konrad Schmid and Markus Witte, eds. T\&T Clark Handbook on the Old Testament: An Introduction to the Literature, Religion and History of the Old Testament. New York: T\&T Clark International, 2012.

Glazier-McDonald, Beth. Malachi: The Divine Messenger. Society of Biblical Literature Dissertation Series 98. Atlanta: Scholars, 1987.

Grabbe, Lester L. A History of the Jews and Judaism in the Second Temple Period. Volume 1. Edited by Lester L. Grabbe and James H. Charlesworth. Library of Second Temple Studies 47. New York: T\&T Clark International, 2004.

Hasel, Gerhard. Old Testament Theology. Grand Rapids: Eerdmans, 1972.

Hendrix, John D. "You Say": Confrontation Dialogue in Malachi." Review and Expositor 84 (1987): 465-477.

Hill, Andrew E. Malachi: A New Translation with Introduction and Commentary. Anchor Bible. New York: Doubleday, 1998.

Hugenberger, Gordon P. Marriage as a Covenant: Biblical Law and Ethics Governing Marriage Developed from the Perspective of Malachi. Vetus Testamentum Supplements 52. Leiden: Brill, 1994.

Jackson, John R. "Abigail or Asherah: Competing Canonical Readings of Malachi 2.12-16." Leaven: A Journal of Christian Ministry 12/1 (2004). Article \#8. Pages 40-48. Cited 12 February 2012. Online: http://digitalcommons.pepperdine .edu/leaven/vol12/iss1/8.

Kaiser, Walter C. Jr. Malachi: God's Unchanging Love. Grand Rapids: Baker Book House, 1984.

Kealy, Sean P. An Interpretation of the Twelve Minor Prophets of the Hebrew Bible: The Emergence of Eschatology as a Theological Theme. Lewiston, N.Y.: The Edwin Mellen Press, 2009.

Kessler, John. "Images of Exile: Representations of the 'Exile' and 'Empty Land' in Sixth to Fourth Century B.C.E. Yehudite Literature." Pages 309-351 in The Concept of Exile in Ancient Israel and Its Historical Contexts. Edited by Ehud Ben Zvi and Christopher Levin. Berlin: Walter de Gruyter, 2010.

. Old Testament Theology: Divine Call and Human Response. Waco, Tex.: Baylor University Press, 2013.

Knoppers, Gary. "Ancient Near Eastern Royal Grants and Davidic Covenant." Journal of the American Oriental Society 116 (1996): 670-697. 
280 Boloje and Groenewald, "Literary Analysis," OTE 28/2 (2015): 257-282

LeCureux, Jason T. The Thematic Unity of the Book of the Twelve. Hebrew Bible Monographs 41. Sheffield: Sheffield Phoenix Press, 2012.

Lee, Kyong-Jin. The Authority and Authorization of the Torah in the Persian Period. Contributions to Biblical Exegesis and Theology 64. Leuven: Peeters, 2011.

Lipschits, Oded. "Demographic Changes in Judah between the Seventh and Fifth

Centuries B.C.E." Pages 323-376 in Judah and the Judeans in the Neo-

Babylonian Period. Edited by Oded Lipschits and Joseph Blenkinsopp. Winona

Lake, Ind.: Eisenbranus, 2003.

. The Fall and Rise of Jerusalem: Judah under Babylonian Rule. Winona

Lake, Ind.: Eisenbranus, 2005.

Lohfink, Norbert. Covenant Never Revoked. New York: Paulist, 1991.

Lopez, René. "Israelite Covenants in the Light of Ancient Near Eastern Covenants."

Chafer Theological Seminary Journal 9/2 (2003): 92-111.

Lundquist, John M. "Temple, Covenant, and Law in the Ancient Near East and in the

Old Testament." Pages 293-306 in Israel's Apostasy and Restoration. Edited by

Avraham Gileadi. Grand Rapids: Baker Book House, 1988.

Mason, Rex A. The Books of Haggai, Zechariah and Malachi. Cambridge Bible

Commentary. London: Cambridge University, 1977.

Mendenhall, George E. "Covenant Forms in Israelite Tradition.” Biblical Archaeologist 17 (1954): 50-76.

Merrill, Eugene H. Haggai, Zechariah and Malachi: An Exegetical Commentary. Chicago: Moody Press, 1994.

Meyers, Eric M. "Priestly Language in the Book of Malachi." Hebrew Annual Review 10 (1986): 225-237.

Miller, Robert D. Covenant and Grace in the Old Testament: Assyrian Propaganda and Israelite Faith. Perspectives on Hebrew Scriptures and its Contexts 16. Piscataway, N.J.: Gorgias Press LLC, 2012.

Nogalski, James D. "Recurring Themes in the Book of the Twelve: Creating Points of Contact for a Theological Reading." Interpretation 61/2 (2007): 125-136.

O'Brien, Julia M. Priest and Levite in Malachi. Society of Biblical Literature Dissertation Series 121. Atlanta: Scholars, 1990. . "Judah as Wife and Husband: Deconstructing Gender in Malachi." Journal of Biblical Literature 115/2 (1996): 241-250. . Nahum, Habakkuk, Zephaniah, Haggai, Zechariah, Malachi. Abingdon Old Testament Commentaries. Nashville: Abingdon Press, 2004.

Ogden, Graham S. "The Use of Figurative Language in Malachi 2:10-16." Bible Translator 39 (1988): 223-230.

Petersen, David L. Zechariah 9-14 and Malachi: A Commentary. Louisville: Westminster John Knox, 1995.

Redditt, Paul L. "Themes in Haggai-Zechariah-Malachi.” Interpretation 61 (2007): 184-197.

."The Book of Malachi in Its Social Setting." Catholic Biblical Quarterly 56/2 (1994): 240-255.

. Haggai, Zechariah and Malachi. New Century Bible Commentary. Grand Rapids: Eerdmans, 1995.

Rendtorff, Rolf. "How to Read the Book of the Twelve as a Theological Unity." Pages 75-87 in Reading and Hearing the Book of the Twelve. Edited by James 
Boloje and Groenewald, "Literary Analysis," OTE 28/2 (2015): 257-282

D. Nogalski and Marvin A. Sweeney. Society of Biblical Literature Symposium Series 15. Atlanta: Society of Biblical Literature, 2000.

Rudolph, Wilhelm. Haggai-Sacharija-Maleachi. Kommentar zum Alten Testament Band 13/4; Gutersloh: Mohn, 1976.

Schmid, Konrad. The Old Testament: A Literary History. Minneapolis: Fortress Press, 2012.

Schuller, Eileen M. “The Book of Malachi." Pages 843-877 in vol. 6 of The New Interpreter's Bible. Edited by Leander E. Keck. Nashville: Abingdon Press, 1996.

Smith, Ralph L. "The Shape of Theology in the Book of Malachi." Scandinavian Journal of Old Testament 30/1 (1987): 22-27.

Stuart, Douglas. "Malachi." Pages 1245-1396 in vol. 3 of The Minor Prophets: An Exegetical and Expository Commentary. Edited by Thomas E. McComiskey. Grand Rapids: Baker Books, 1998.

Stulman, Louis and Hyun C. P. Kim. You are My People: An Introduction to the Prophetic Literature. Nashville: Abingdon Press, 2010.

Sweeney, Marvin A. "Sequence and Interpretation in the Book of the Twelve." Pages 49-64 in Reading and Hearing the Book of the Twelve. Edited by James D. Nogalski and Marvin A. Sweeney. Society of Biblical Literature Symposium Series 15. Atlanta: SBL, 2000.

.TANAK: A Theological and Critical Introduction to the Jewish Bible. Minneapolis: Fortress Press, 2012.

Tiemeyer, Lena-Sofia. "Giving a Voice to Malachi's Interlocutors." Scandinavian Journal of the Old Testament: An International Journal of Nordic Theology 19/2 (2005): 173-192.

. Priestly Rites and Prophetic Rage: Post-exilic Prophetic Critique of the Priesthood: Forschungen zum Alten Testament 2/19. Tubingen: Mohr Siebeck, 2006.

Udoekpo, Michael U. Re-Thinking the Day of YHWH and the Restoration of Fortunes in the Prophet Zephaniah: An Exegetical and Theological Study of 1:14-18; 3:14-20. Bern: Peter Lang AG, 2010.

Van der Toorn, Karel. Scribal Culture and the Making of the Hebrew Bible. London: Harvard University Press, 2007.

Von Rad, Gerhard. Old Testament Theology. Volume 1. New York: Harper \& Row, 1962.

Wallace, Howard N. and Steven L. Mackenzie. "Covenant Themes in Malachi." Catholic Biblical Quarterly 45/4 (1983): 549-563.

Waltke, Bruce K. "The Phenomenon of Conditionality within Unconditional Covenants." Pages 123-139 in Israel's Apostasy and Restoration: Essays in Honor of Roland K. Harrison. Edited by Avraham Gileadi. Grand Rapids: Baker, 1988.

Watts, John D. W. "A Frame for the Book of the Twelve: Hosea 1-3 and Malachi." Pages 209-218 in Reading and Hearing the Book of the Twelve. Edited by James D. Nogalski and Marvin A. Sweeney. Society of Biblical Literature Symposium Series 15. Atlanta: SBL, 2000.

Wells, Richard C. "The Subtle Crises of Secularism: Preaching the Burden of Israel." Criswell Theological Review 2/1 (1987): 39-61. 
282 Boloje and Groenewald, "Literary Analysis," OTE 28/2 (2015): 257-282

Weyde, Karl W. Prophecy and Teaching: Prophetic Authority, Form Problems, and the Use of Traditions in the Book of Malachi. Beihefte zur Zeitschrift für die Alttestamentliche Wissenschaft 288. Berlin: Walter de Gruyden, 2000.

Blessing Onoriode Boloje \& Alphonso Groenewald, Department of Old Testament Studies, Faculty of Theology, University of Pretoria, 0002, Pretoria. Email: pstbobson@yahoo.co.uk \& alphonso.groenewald @up.ac.za. 